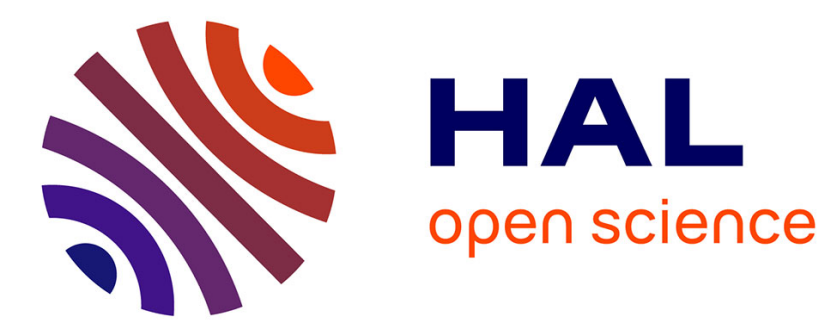

\title{
Special Section: Advances in Manufacturing Systems and Logistics
}

\author{
Alexandre Dolgui, Gérard Morel
}

\section{To cite this version:}

Alexandre Dolgui, Gérard Morel. Special Section: Advances in Manufacturing Systems and Logistics. Annual Reviews in Control, 2007, 31 (1), pp.105-106. 10.1016/j.arcontrol.2007.03.001 . hal-00163166

\section{HAL Id: hal-00163166 https://hal.science/hal-00163166}

Submitted on 16 Jul 2007

HAL is a multi-disciplinary open access archive for the deposit and dissemination of scientific research documents, whether they are published or not. The documents may come from teaching and research institutions in France or abroad, or from public or private research centers.
L'archive ouverte pluridisciplinaire HAL, est destinée au dépôt et à la diffusion de documents scientifiques de niveau recherche, publiés ou non, émanant des établissements d'enseignement et de recherche français ou étrangers, des laboratoires publics ou privés. 


\section{Special Section: Advances in Manufacturing Systems and Logistics}

\section{Guest Editorial}

We have a pleasure to introduce this section of the IFAC journal Annual Reviews in Control which contains some keynote papers and a selected survey of the $12^{\text {th }}$ IFAC INCOM'06 Symposium on Information Control Problems in Manufacturing (Dolgui et al., 2006).

Current and emerging manufacturing and logistics systems are posing new challenges and opportunities for the automation and control community which are addressed by the IFAC coordinating committee CC5 on Manufacturing \& Logistics Systems (Nof et al., 2006) and its four TCs contributing to Manufacturing Plant Control, Manufacturing Modelling for Management and Control, Enterprise Integration and Networking and Large Scale Complex Systems.

The symposium INCOM'2006 ${ }^{1}$ was a significant event for this community. It was scientific and industrial happening, lifting the spirits of all who participated. Taking place from 17th to 19th of May, 2006 in Saint Etienne (France), the symposium was organized by the Division for Industrial Engineering and Computer Sciences (G2I Division) of the Ecole des Mines de Saint Etienne (ENSM.SE) and sponsored by IFAC, IFIP, IFORS, IEEE, IMS, EURO, ROADEF, GDR MACS/CNRS (French National Council for Scientific Research) and by several European scientific projects and networks, as for example, CODESNET, INTEROP, I-PROMS, PROMISE, etc.

INCOM's philosophy was simple: put industrial problems in the forefront and invite all possible players in Manufacturing Automation, Operational Research and Industrial Engineering, to regard and propose solutions. This approach, which smashed the barriers between disciplines, made INCOM06 the major scientific and industrial event in Manufacturing Systems and Logistics in 2006. INCOM'2006 in numbers:

603 papers were submitted from 57 countries;

783 attendees: 544 academics and 239 industrial representatives;

98 sessions in the final program;

42 industrial exhibitors;

2665 pages of symposium proceedings with 950 authors.

Thus, this special section promises to be broadly based and representative. The special section papers give an excellent overview of major problems in Manufacturing Systems and Logistics, and present advanced methods and promising research paths. Written by leading scientists, these articles are rich in outstanding ideas, and lend an air of authority and diverse perspectives to our field.

The paper "Analysing Industrial District Performances: A Structured Approach" by Agostino Villa is an informative and engaging presentation of the new and promising concept of Industrial Districts. This contribution reveals important problems for small and medium sized enterprises and

\footnotetext{
${ }^{1}$ www.emse.fr/incom06
}

Dolgui A., Morel G., Pereira C. (2006) Editors, Information Control Problems In Manufacturing 2006: A Proceedings volume from the 12th IFAC International Symposium, St Etienne, France, 17-19 May 2006, Elsevier Science, 2006, ISBN: 978-0-08-044654-7, IFAC Publications, 3 volumes.

Nof S.Y., Morel G., Monostori L., Molina A., Filip F. (2006). From plant and logistics control to multi-enterprise collaboration. IFAC Annual Reviews in Control, 30/1/55-68. 
some novel ideas on their possible organizational networking. Broader and more complex industrial structures are available to study. This analysis identifies the most important features of an industrial district, as well as the most evident conditions which could be a weakness for a district. The "best practices" approach is justified and explained for the district design and management, and offering suggestions to both the district managers and local politicians. Also this article provides some information on the activities of a European Consortium of research laboratories formed for the European Coordination Action CODESNET (COllaborative DEmand \& Supply NETwork). Several excellent hints are derived from the outlined analysis and examination of the industrial districts collected within the CODESNET project.

The paper "A Framework for Virtual Organization Creation in a Breeding Environment" by Luis M. Camarinha-Matos and Hamideh Afsarmanesh presents the concept of virtual organization in the framework of a collaborative network. The possibility of rapidly forming a Virtual Organization with several partners is an expression of agility and survival mechanism in face of market insatiability. This paper proposes a framework for creation of a virtual organization developed by IST ECOLEAD integrated project, which involves 27 partners from 15 countries in Europe, Brazil and Mexico. The paper explains that the process of virtual organization creation mainly depends on the availability of adequate information about potential partners and their level of preparedness for this action. The proposed approach takes into account past experiences and details all required steps from the identification of the collaboration opportunity till the actual realization. This paper is crucial for all those who envision mounting or studying the creation of a virtual organization. These two authors have put an extraordinary amount of energy to develop and promote this new and interesting topic.

A leading specialist in Enterprise Modelling François B. Vernadat, in the paper entitled "Interoperable Enterprise Systems: Principles, Concepts, and Methods", spotlights the new challenges and difficulties for Enterprise Integration in the modern economical situation linked with Supply chain concepts and globalization. Enterprise Integration, in this context, is one way to support management and control of networked interoperable enterprise systems. This article discusses architectures and methods to build interoperable enterprise systems, advocating a mixed service and process orientation, to support synchronous and/or asynchronous operations, both at the business and at the application levels. The paper promotes a service-oriented architecture sustaining business process orchestration, this architecture itself relying on an Enterprise Service Bus. The author furnishes a superb panorama of existing techniques, ideas and approaches. Well-known in this field, François B. Vernadat once again has given us an interesting analysis which we are sure will be useful for many researchers and industrial experts.

Andrew Kusiak and Matthew Smith in their survey "Data Mining in Design of Products and Production Systems" present data-mining applications. This is a broad and expanding area which plays an increasingly important role. The goals may range from obtaining a general understanding of the nature of data to very accurate modeling and forecasting of different phenomena. Companies are increasingly developing data warehouses to collect and store different business information. Data-mining algorithms can not only extract the static patterns in data, but can also discover dynamic trends. The authors show areas and problems in product life cycle and production system management which are particularly suitable for data-mining approaches. A classification of datamining algorithms is proposed. More representative techniques are presented. Then, the authors focus on the Industrial Engineering applications for Knowledge Discovery, Data-Driven Design, Mass Customization, Supply Chain Management and Data-Driven Innovation. The authors outline the areas of innovation as the most lasting value suitable for data-mining techniques. The paper is very pedagogical with several interesting examples. It points out the major challenges for research and show potential applications of this type of technique for design and management of products and production systems. The advantages for industrial enterprises are evident and numerous. 
Finally, Jean-Marie Proth with his paper "Scheduling: New Trends in Industrial Environment" gives an analysis of scheduling approaches and their applicability in modern production systems. The author briefly recalls the past evolution of scheduling activities in industrial environments. Then, he describes the current situation and emphasizes the problems that need solutions. After a brief description of the basic scheduling concepts and definitions, this state-of -the-art paper positions the techniques of scheduling in the context of the Supply chain paradigm. Historically, the scheduling theory was developed for the deterministic systems. From 60's to 90's the deterministic scheduling approaches were at the heart of the scientific research and attempts for industrial applications. A lot of efforts were made and theoretical results were obtained. Therefore, in the new situation of the production systems management with the Supply chain concept, the deterministic approaches are less important and placed on the strategic level. At the tactical and operational level, the real-time scheduling is necessary. This is a real challenge for today. Jean-Marie Proth gives a synthesis of different exigencies of Supply chain management and proposes a clear vision of the perspectives for real-time scheduling. This is an excellent contribution from an author experienced in research and contractual activities in Scheduling and Supply chain management.

We would like to thank the authors for their contributions and the referees for the time they put in reviewing all papers. Thanks to Professor Janos J. Gertler, Editor-in-chef of the IFAC journal Annual Reviews in Control, for his support and the possibility to publish this special section.

Pr. Alexandre Dolgui

General Scientific Chair

Pr. Gérard Morel

Chair of International Program Committee

\section{Special Section References}

Agostino Villa, Analysing industrial district performances: A structured approach, Annual Reviews in Control, doi:10.1016/j.arcontrol.2007.03.002

Luis M. Camarinha-Matos and Hamideh Afsarmanesh, A framework for virtual organization creation in a breeding environment, Annual Reviews in Control, doi:10.1016/j.arcontrol.2007.03.006

F.B. Vernadat, Interoperable enterprise systems: Principles, concepts, and methods, Annual Reviews in Control, doi:10.1016/j.arcontrol.2007.03.004

Andrew Kusiak and Matthew Smith, Data mining in design of products and production systems, Annual Reviews in Control, doi:10.1016/j.arcontrol.2007.03.003

Jean Marie Proth, Scheduling: New trends in industrial environment, Annual Reviews in Control, doi:10.1016/j.arcontrol.2007.03.005 